\title{
Understanding the WTO Sanitary and Phytosanitary Agreement ${ }^{1}$
}

Edward A. Evans ${ }^{2}$

\section{Introduction}

This publication is part of the Understanding Trade Policy Issues series. International trade liberalization and the general globalization of the world economy over the past two decades has meant that growers, businesses, and community groups must become familiar with trade polices and their terminologies to reap the benefits of globalization and to minimize costs. Consequently, the aim of this series is to help people understand the issues involving the benefits and problems associated with global trade.

This publication, the first of the series, discusses the term "WTO-SPS Agreement" (the Sanitary and Phytosanitary Agreement under the World Trade Organization).

\section{What Is the WTO Sanitary and Phytosanitary (WTO-SPS) Agreement?}

WTO is the acronym for World Trade Organization. It is the only international body that sets and oversees the global rules of trade between nations. At the heart of the WTO is a set of agreements, negotiated and signed by the bulk of the world's trading nations and ratified by their governments. These agreements are the legal ground rules for international commerce. They encourage governments to keep their trade policies within agreed limits to everybody's benefit (http://www.wto.org).

The Sanitary (human and animal safety) and Phytosanitary (plant safety) Agreement (SPS Agreement) is one such agreement forming part of the 1994 Accords that established the WTO, which replaced the General Agreement on Tariffs and Trade (GATT). Regulations

( http://www.wto.org/english/tratop_e/sps_e/sps_e.htm ) under the purview of the WTO-SPS Agreement include:

- the protection of animal or plant life or health within a territory from risks arising from the entry, establishment, or spread of pest, disease, disease-carrying organisms, or disease-causing organisms.

- the protection of human or animal life or health within a territory from risks arising from additives, contaminants, toxins, or

1. This is EDIS document FE492, a publication of the Department of Food and Resource Economics, Florida Cooperative Extension Service, UF/IFAS, University of Florida, Gainesville, FL. Published August 2004. Please visit the EDIS website at http://edis.ifas.ufl.edu.

2. Edward A. Evans, Assistant Professor, Department of Food and Resource Economics, Tropical Research and Education Center, Homestead, FL, Florida Cooperative Extension Service, UF/IFAS, University of Florida, Gainesville, FL. 
disease-causing organisms in foods, beverages, or feedstuffs.

- the protection of human life or health within a territory from risks arising from diseases carried by animals, plants, or products thereof, or from entry, establishment, or spread of pests.

- the prevention or reduction of the risks of other damages within a territory from the entry, establishment, or spread of pests (Appendix A of WTO-SPS Agreement 1994, Annex A).

\section{What Is the Economic Rationale for Governments to Become Involved?}

The rationale for involving governments in establishing policies and implementing measures to prevent or control the introduction and spread of invasive pests and diseases can be found in the economic concepts of public services (goods) and externalities. As defined here, public service/good is something that provides a "free rider" benefit (it is available to everyone). Since no one can take ownership, the government assumes the responsibility of providing public services/goods (recouping costs by means such as taxation). One example of a public service is the measures aimed at preventing or controlling the spread of invasive pests and diseases. The concept of a public service can easily be extended to global public service when there is cooperation among governments of many countries to take action to reduce, say, the threat of invasive pests and diseases.

An externality arises when the action or inaction of one party affects another party in a positive or negative manner without the party responsible for the action or inaction being rewarded if the impact is positive or charged if the impact is negative. For example, a negative externality may arise when imported goods arrive accompanied by invasive pests or diseases, which may reduce domestic output and/or increase production costs. Usually the exporting country is not made to stand the cost of damages to the importing country. In such cases where the market mechanisms alone fail to prevent or correct such negative externalities, then governments are justified in providing regulations (public services) that will prevent entry or reduce the risks of the threat.
The need for a government to protect its citizens and environment against imported externalities (such as invasive pests and diseases) is recognized and embraced by the WTO Agreement (discussed below), which promotes increased trade among countries. Take, for example, the following two scenarios:

- In the first scenario, government-imposed regulations to protect human and environmental resources from negative externalities (e.g., the threat of harmful organisms) through trade barriers may benefit a country.

- In the second scenario, regulations imposed for the sole purpose of protecting domestic producers from international competition may harm a country.

The first scenario is acceptable to the WTO, but the second scenario is not. It is this dual nature of the SPS regulations-having on the one hand the potential to provide genuine protection, while on the other hand the potential to be used for economic-based protection - that has made their implementation so contentious and has signaled the need for an SPS Agreement among governments.

\section{Why Does the WTO-SPS Agreement Promote Free Trade?}

The main purpose of the WTO-SPS Agreement is to promote free trade. In principle, a country can increase its real national income by more efficiently utilizing its limited resources and engaging in mutual trade, which means consumers can enjoy a higher level of satisfaction and producers can sell their products in an expanded market. In general the global economy as a whole is expected to benefit. However, when such trade encounters negative externalities or hidden costs (e.g., from importing harmful pests and diseases), acceptance of the general premise becomes blurred. The gains from trade are no longer a certainty.

\section{What Is the Genesis of the WTO-SPS Agreement?}

The decision to negotiate a separate Agreement on the Application of Sanitary and Phytosanitary Measures during the 1986-1994 GATT Uruguay 
Round of multilateral trade negotiations marked a turning point in the development of multilateral trade rules and gave prominence to issues related to agricultural trade and the risk of importing invasive pests and diseases and food-borne illnesses. Although the SPS measures were recognized as having the potential to impede trade and were considered important under previous GATT rounds, they were relegated to being included as parts of other agreements and as exceptions to the main provisions fostering increased trade. [SPS measures were found in the original GATT Articles, mainly Article XX "General Exceptions," and later in the 1979 Tokyo Round Agreement on Technical Barriers to Trade, a plurilateral agreement known as the Standards Code (

http://www.wto.org/english/thewto_e/whatis_e/tif_e/ fact4_e.htm).] The impetus for negotiating a separate Agreement for SPS measures and for bringing quarantine issues to the forefront can be attributed to the deeper integration of agriculture into the international trading system (open markets and free trade) in general and to the decision to discipline the use of quantifiable nontrade barriers (quotas, subsidies, and licenses) in particular. Many countries, including the United States, feared that, with a reduction in the use and levels of these support measures, some importing countries might turn to technical trade barriers (notably SPS measures) as a means of allowing them to continue providing support to their farming community. Consequently, the intent of the Agreement was to ensure that when SPS measures were applied, they were used only to the extent necessary to ensure food safety and animal and plant health, and not to unduly restrict market access for other countries (James and Anderson, 1998; Roberts, 1998).

\section{What Are the Main Provisions of the WTO-SPS Agreements?}

To achieve its objectives, the WTO-SPS Agreement contains a set of substantive and procedural provisions. The substantive provisions are aimed at protecting human, animal, and plant health and life while preventing unjustifiable barriers to trade. The procedural provisions create a framework to improve communication between members regarding proposed SPS changes and to provide a forum for dispute settlement.

The WTO-SPS Agreement creates a framework for border protection and eradication measures while facilitating freer trade. The Agreement is based on the following five general principles:

\section{Harmonization - encourages the adoption of} measures that conform to international standards, guidelines, and/or recommendations of international agencies.

2. Equivalence-mutual recognition of different but equivalent measures to achieve international standards.

3. Non-discriminatory-treating imports no differently than domestic produce.

4. Transparency-notifying trading partners of changes in their SPS measures, especially when the measures differ from international standards.

\section{Regionalization-allows continued exports from} clean (disease-free) areas of affected countries.

The Agreement reaffirms the freedom of countries to choose their appropriate level of protection against imported pests and pathogens. However, when the measures do not conform to international standards, the importing country must scientifically investigate why the measures are needed and how they control risk.

The main substantive provisions can be found in Articles 5 and 6:

- Article 5.1, requires members (when possible and as appropriate) to base their SPS measures on risk assessment methodologies developed under the auspices of the appropriate relevant international organization.

- Article 5.2 stipulates that countries should consider direct risk-related costs (e.g., potential production or sales losses or control and eradication costs) both in assessing and managing risks through the choice of an SPS measure to protect plant or animal health. 
- Article 5.5 states that each member is also obligated to avoid arbitrary or unjustifiable distinctions in the levels of protection it considers to be appropriate (if these distinctions would result in disguised restrictions on international trade) to achieve the objective of consistency in the application of SPS measures.

- Article 6 requires that import protocols be based on risk assessments that evaluate the claims by exporting countries that certain regions are free of quarantine diseases or pests, or that the prevalence of quarantine pests and disease is low.

\section{How Has the WTO-SPS Agreement Faired To-Date?}

The jury is still out on the overall performance of the WTO-SPS Agreement. On the one hand, the Agreement has successfully facilitated international trade - the main purpose of the Agreement—judging from the number of disputes that have been settled. On the other hand, it has also increased the risk of bioinvasion (i.e., foreign pests and diseases entering a country). By restraining a country's sanitary and phytosanitary regulations, the Agreement has weakened national protections against bioinvasion (McNeely, 1999). This comes at a time when global concerns for the environment are outpacing the development of proven control technologies (FAO, 2001). The global spread of unwanted pests and diseases has increased significantly, as have their control costs. For example, Figure 1 illustrates the effect of Bovine Spongiform Encephalopathy (BSE), commonly referred to as "Mad Cow Disease," which is a slowly progressive, degenerative, fatal disease affecting the central nervous system of adult cattle. Since first being identified in 1986, there have been more than 180,000 cases reported worldwide, with 95 percent of the cases occurring in the United Kingdom (UK). The disease has been linked to the fatal human illness Creutzfeldt-Jacob Disease (CJD). The exact origin of BSE remains uncertain but it was apparently transmitted to cattle in feed supplements that contained meat and bone meal. There is currently no method for diagnosis in early stages of infection and no cure for the disease, either in animals or in humans. USDA spending, for example, on its emergency eradication program increased from approximately $\$ 10$ million dollars per year in the early 1990s to $\$ 334$ million dollars per annum in 2001 (USDA Briefing Room, 2003).

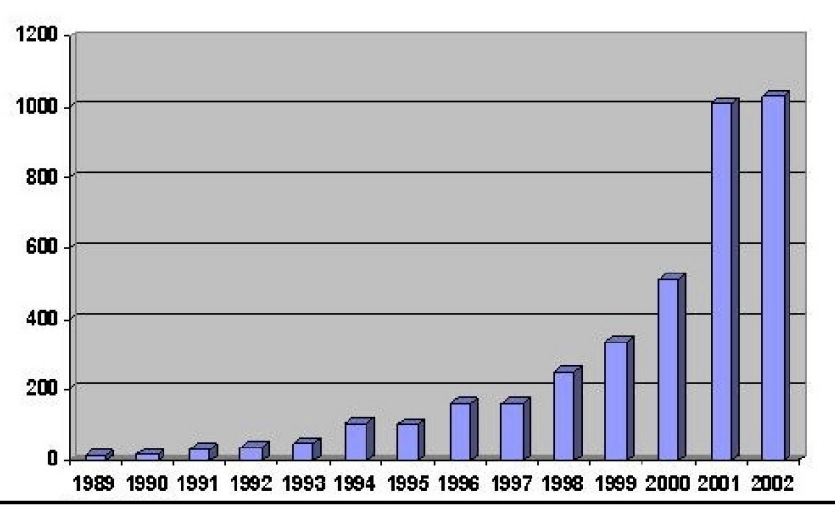

Figure 1. Number of reported cases of bovine spongiform encephalopathy worldwide (excluding UK), 1989-2002. Source: OIE (World Organisation for Animal Health)

\section{Final Comments}

The challenge confronting member countries is how to balance unique regulatory needs against the general goal of freer trade (enjoying the benefits that come with trade liberation and globalization while simultaneously minimizing the risks of the introduction and spread of pests, weeds, and diseases). A global SPS Agreement helps, but it is not a panacea. The main purpose of the WTO-SPS Agreement is to facilitate trade. However, we need to make sure that the benefits attained from trade can be sustained. Imports of harmful organisms could easily erase such gains. It must be remembered that a country's first line of defense is prevention and that prevention is always less costly than eradication.

\section{References}

Food and Agricultural Organization (FAO). 2001. The State of Food and Agriculture 2001. Rome, Italy: FAO.

James, S., and K. Anderson. 1998. On the Need for More Economics Assessment of Quarantine Policies. Australian Journal of Agricultural and Resource Economics 42(4):425-444.

McNeely, J.A. 1999. An Introduction to Human Dimensions of Invasive Alien Species. In The Great Reshuffling: Human Dimensions of Alien Invasive 
Species, edited by J.A. McNeely, pp 5-22. Gland, Switzerland: IUCN Publishers.

Roberts, D. 1998. Implementation of the WTO Agreement on the Application of Sanitary and Phytosanitary Measures.. Agriculture in the WTO/WRS-98-44. Economic Research Service, United States Department of Agriculture, Washington, D.C.

USDA Briefing Room. 2003. Invasive Species Management: Trends in Emergency Program Expenditures. http://www.ers.usda.gov/briefing/invasivespecies/ indemnities.htm.

USDA. 2003. Floriculture and Nursery Crops Situation and Outlook Yearbook. FLO2003, Market and Trade Economics Division, Economic Research Service, USDA, Washington, D.C. (June).

World Trade Organization (WTO). 1995. Agreement on the Application of Sanitary and Phytosanitary Measures. In Results of the Uruguay Round of Multilateral Trade Negotiations: The Legal Texts. Geneva, Switzerland: WTO.

World Trade Organization (WTO) website at http://www.wto.org. 